\title{
Energy Renovation Models in Private Households in Denmark
}

Tjørring, Lise; Gausset, Quentin

Published in:

Community Governance and Citizen Driven Initiatives in Climate Change Mitigation

Publication date:

2016

Document version

Version created as part of publication process; publisher's layout; not normally made publicly available

Citation for published version (APA):

Tjørring, L., \& Gausset, Q. (2016). Energy Renovation Models in Private Households in Denmark. In J. Hoff, \& Q. Gausset (Eds.), Community Governance and Citizen Driven Initiatives in Climate Change Mitigation (pp. 89106). Routledge. 


\title{
6 Energy renovation models in private households in Denmark
}

\author{
Lise Tjørring and Quentin Gausset
}

\section{Introduction}

In 2011, the Danish Ministry of Energy and Climate launched a new national energy strategy to contribute to the mitigation of climate change and global warming (Danish Ministry of Climate, Energy and Building 2011). This strategy stipulates that by 2020,50 per cent of the country's electricity consumption should come from renewable sources and that the country should be fossil-free by 2050.

Reducing energy consumption in private households is an important part of this strategy: consumption at the household level constituted 28 per cent of the total national energy consumption in 2011. [Transport, the second biggest source of energy consumption, accounted for 26 per cent of the total (see Danish Energy Agency 2012, 20).] According to the National Register for Buildings and Habitations (BBR), Danish houses in a municipality like Sonderborg, one of the case studies analysed in this chapter, are an average of 65 years old and were built before any energy standards were implemented in the country. Hence, there is a great potential for reducing the energy consumption by targeting these older private households.

There are two main public actors involved in trying to reduce energy consumption at the household level: energy companies and municipalities. On the one hand, the Danish government compels Danish energy companies to reduce their clients' energy consumption by 10.7 Petajoule (PJ) annually in 2013-2014 and by 12.2 PJ annually in 2015-2020 (Energispareaftale 2012). Thus, energy companies have to convince their clients (including private households) to save on conventional energy by investing in green energies and/or by reducing their energy consumption.

On the other hand, even though the Danish government does not compel municipalities to develop local climate plans, 72 per cent of Danish municipalities have done so voluntarily (Hoff and Strobel 2013). Climate plans are developed because they can be used to brand and give a positive image to the municipalities and to the local politicians who develop them. They can also help municipalities realise substantial energy savings and create 'green jobs' in the municipality (Hoff and Strobel 2013). 
Some Danish municipalities have developed pilot projects in collaboration with energy companies that are designed to reduce energy consumption by promoting home energy renovation. This chapter reviews four of the best-known and successful projects: ZEROhome in Sonderborg, ESCO-light in Middelfart, MyClimatePlan in Middelfart and Green Business Growth (GBG) in Kolding, Middelfart and Odense. All these projects are public-private partnerships between municipalities and energy companies intended to trigger new renovation projects in Danish households with the help of energy advisers who provide homeowners with energy reports on their houses and builders who receive training in energy savings and 'green' renovation.

All these projects meet the same challenges:

- What is the best way to approach people about the benefits of home renovation (information campaigns in the media, neighbourhood meetings, social networks, green ambassadors)?

- Which actor is the most successful in convincing people to renovate their homes - energy advisers, builders, municipal agents, neighbours?

- What are the best arguments to convince people to renovate their houses economic savings and payback period? Comfort? Reduction of carbon dioxide $\left(\mathrm{CO}_{2}\right)$ ? A mix of these?

- What is the best method to subsidise energy consultation and energy renovation?

- How can we evaluate whether the project has triggered additional and new renovations that were not already planned?

- How can an existing project continue to operate when its budget is exhausted?

In order to deepen our understanding of the different home renovation models and evaluate their strengths as well as their weaknesses, we describe and discuss below how these projects have addressed the challenges listed above as well as the difficulties they encounter during the renovation process. Our goal is to provide these four energy renovation models as inspiring examples of social technologies that create synergies between citizens (private households) and institutions (energy companies and municipalities) to reduce energy consumption at the local level - an important step in the journey to meet the climate challenge.

\section{Method}

The data presented in this chapter were collected between 2011-2013 by different methods. MyClimatePlan had already ended by the time the research for this chapter began; for data about this project we relied primarily on secondary literature and on interviews of the head of the project and two participants. We also participated in three meetings about a future low-energy village project that had been triggered by MyClimatePlan. 
We studied ESCO-light by participating in a variety of meetings spread over the entire life of the project, including both information meetings for citizens and managerial meetings with energy companies and builders. We also monitored the production of three energy reports for specific households, conducted interviews with the project managers, three builders and two customers (or 'beneficiaries') and participated in two conferences at which the results achieved by Esco-light were presented and debated.

Green Business Growth was studied by participating in two energy fairs (including preparation and evaluation meetings), and by interviews with the managers of the project and two builders. Fieldwork in the ZEROhome project included participant observation and semi-structured interviews with ten families; first, during their meetings with the energy adviser of the project, and periodically for the next six months. We also attended several bi-weekly meetings of the ZEROhome project group.

\section{Presentation of the four models}

\section{The ZEROhome model}

ZEROhome began in 2010 with the goal to promote energy-friendly behaviour and energy renovations in private households in the municipality of Sonderborg in southern Denmark. It was part of ProjectZero, which is a public-private partnership organisation focused on creating a $\mathrm{CO}_{2}$-neutral municipality by 2029. ProjectZero itself was established in 2007 by Sonderborg municipality, the private companies of South Energy (Danish energy company), DONG Energy (Danish Oil and Nature Gas, a Danish energy company), Danfoss (an international company producing components and solutions including renewable energy solutions) and by the Nordea Fund (established by the Nordea Bank). The overall focus of ProjectZero is: 1) to reduce energy consumption not only in private households, but also in private companies and public institutions, and 2) the conversion of energy sources to local renewable sources such as biomass, biogas, solar heat, wind power and geothermal energy in the areas of district heating and electricity production. Another objective of ProjectZero is to combine the development of $\mathrm{CO}_{2}$ neutral energy production with economic growth that generates green jobs in the area.

ZEROhome offered free energy advice, and recruited private households through advertisements posted by ProjectZero in the local newspapers, by word of mouth and in other public campaigns. In addition, ProjectZero hosted a stand at the annual housing fair in the municipality, where visitors could sign up directly for free energy advice for their homes. ProjectZero also began cooperating with all local banks in the area. The banks arranged information evenings for their customers to encourage them to consider an energy renovation of their house. They also offered to help with loans and arranged free energy advice by ZEROhome for their customers. 


\section{Tjørring and Gausset}

When the members of private households signed up for free energy advice, they were asked to complete a form about the condition of their house, including its age, source of heating, the thickness of wall and loft insulation and the number of residents in the house. Houses that were constructed after 1996 were not chosen for renovation assistance because these houses had complied with the relatively high standard building regulations of that year and because there was more potential for positive energy results by focusing on reducing energy consumption in older houses.

After completing the form, homeowners waited for approximately one month for a visit from the energy adviser. The energy adviser began the visit by discussing with family members how they could reduce their energy consumption by changing habits, avoiding using electricity on stand-by and replacing old domestic appliances such as refrigerators and freezers with energy-saving models. The energy adviser then asked the family for a tour of the entire house to review the types of windows and toilets, the suitability of the roof for installation of solar panels, the setting on the heating source and the central heating pump, among others. He also measured the thickness of the insulation in the attic and estimated the insulation standard in the walls.

Based on his observations, the energy adviser then discussed the different options for energy improvement with the family and made a list in order of priority of the most economically profitable energy investments. Because every house is different, the energy adviser's recommended list of investments varied from house to house. However, some of the most common recommendations included replacing old windows with low-energy windows, converting from oil and gas to district heating and investing in additional insulation. After the visit, the energy adviser mailed the family a report that was customised to the specific house. The family was also given a list of the builders in the municipality who had completed an energy course; in the interest of impartiality, the energy adviser did not recommend a specific builder.

The ZEROhome project received a lot of favourable media attention, both on national and European levels. In 2012, ZEROhome was designated as a 'European role model in energy advice' by the European Union (EU) (ProjectZero 2013). Because of the project's potential to lower energy consumption in private households and create green jobs among builders, it was generally presented by the national media as a model to be followed by other municipalities. In the 3-year-period from 2010 to 2013, 1,109 home owners received energy advice from ZEROhome; 61 per cent of these households made energy renovations that totalled 103 million Danish Kroner (DKK), which at the current exchange rate equals 13.9 million Euros.

Since its funding period expired in June 2013, ZEROhome has been reconfigured. Instead of offering costly free energy advice, it has developed an education programme for builders who want to become energy advisers. To date, 80 building companies have completed the training programme. 


\section{MyClimatePlan and ESCO-light models}

The municipality of Middelfart takes pride in being one of the first 'green growth' municipalities in Denmark. It has been spearheading the introduction of the ESCO ('Energy Service Company') concept in Denmark, which is a financing model by which a company conducting energy renovation in bigger buildings, e.g. offices and schools, can guarantee a certain level of energy savings. The payment of the renovation is directly financed by the energy savings realised. In this way, municipalities are able to renovate their municipal buildings without having to increase their municipal budget. The municipality continues to pay the same operating cost to heat its communal buildings as it did before the renovation; the savings realised from the energy renovation finances the cost of renovating the buildings over a period of two to fifteen years. At the end of this period, the municipality has gained the full benefit of the energy savings and can then reduce its operational costs.

Having had some success with the original ESCO model, the municipality then decided to help its citizens benefit from energy renovation. However, the model required some adjustments in order to apply it to home renovation. This model adapts well to bigger municipal buildings because their operational costs are large and relatively stable over time. However, it is much more difficult to apply the model to energy renovations to houses. Because houses are smaller than municipal buildings, it is more difficult to guarantee energy savings, and the energy consumption can be subject to wide variations.

Middelfart municipality then devised a new approach to trigger energy renovation in private buildings that was first called 'minklimaplan' (MyClimatePlan) and later re-named 'ESCO-light' (although the model in practice is very different from the traditional ESCO model).

MyClimatePlan began in March 2008 and ended in January 2010. The municipality offered free home energy evaluations to any group of a minimum of 10 citizens living in the same neighbourhood. On a given date, an energy adviser from the local energy company, two representatives from the municipality and two builders (one plumber and one carpenter/mason) visited the different houses to identify those with the highest potential for energy and monetary savings. These procedures are similar to those used in the ZEROhome project described above. The adviser then sent an energy report to each household, and the builders sent an offer covering the different points mentioned in the report. People were free to select which problems (if any) they wished to address, and were free to choose another builder.

However, they were also promised a 15 per cent cost reduction from the builder who had made the first offer, under the condition that the renovation be conducted at the same time as the other members of the neighbourhood group. This was justified by the fact that the builders could save money on transport when working for several families living in the same neighbourhood, and could save money when ordering the same kind of material in larger quantities. Renovating houses in the same neighbourhood, which were generally built 
during the same period, maximised the chance that the material requested in one house would be the same or similar to that requested in neighbouring houses.

A total of 89 houses benefitted from the initial offer and received an energy report. Most of them went further to address some of the problems mentioned. Some did it themselves, others relied on builders (often those who had visited their home). Moreover, some did it together with the other members of the group, while others waited a few months until certain circumstances in their personal lives allowed them to invest in energy renovation.

The ESCO-light project began in March 2011 in Middelfart as a continuation of MyClimatePlan. One of the major problems identified in MyClimatePlan was the large amount of human resources invested in energy consultation, which was paid for by the municipality and provided free of charge to citizens. To avoid this problem, the municipality, in collaboration with local energy companies, decided to train builders (and other people working in manual trades) in energy counselling. The municipality devised a three-day training for builders that focused on different aspects of energy renovation and on how to calculate precisely and with confidence the number of kilowatt-hour ( $\mathrm{kWh}$ ) saved for each type of renovation. After this training, builders were then able to deliver to their clients individual energy reports that described the potential energy savings that could be made, how much they would cost, and how long the payback period would be. The builders would also be available to help their clients to sell these savings to energy suppliers.

The municipality then organised a series of four meetings (advertised in local newspapers) to inform its residents about the new possibilities offered by ESCOlight. Individual households were then free to choose a builder from the list of those who had taken the ESCO-light training, who would then visit their houses and provide an energy report. Households could then decide whether they wanted to invest in all or in a restricted number of the recommendations made.

From the point of view of the end users, this project provided both free and qualified energy counselling as well as an additional subsidy to individuals who renovated their houses. The advantage for builders was that they increased their knowledge about energy renovation and gained an edge in a growing niche market. They also benefitted from increased visibility in the general building market: the municipality advertised the project in local media, and the municipality awarded diplomas to the builders for the training course that could be used in the builders' marketing of their businesses. Energy companies could also outsource to the builders some of the burden linked to generating energy savings in private households.

As for the municipality, this project was an important component of their $\mathrm{CO}_{2}$ reduction goal. In addition, more renovation projects would create more jobs in the building industry and generate more tax revenues to the municipality. Thus, the project created a sustainable, win-win situation for all stakeholders. 


\section{Green Business Growth}

'Green Business Growth', or GBG, is a public-private partnership that includes four municipalities (Middelfart, Kolding, Odense and Faaborg-Midtfyn), several builders and energy companies, teaching institutions and local banks (see www.groenerhvervsvaekst.dk). The project began in 2010 and was the initiative of the Middelfart municipality, which wanted to test a new approach based upon its experience with previous climate change mitigation projects. It received funds from the EU, the region of southern Denmark and participating municipalities, and is still running today. Its main goal is to create 300 jobs in the building industry by promoting energy renovations in private households as well as in public buildings, businesses and offices.

The activities developed by GBG are built on the experience of past similar projects and are eclectic. Like ESCO-light, GBG has organised several educational training sessions for builders, and promotes the builders who receive their training certificates. It also offers free energy counselling to individuals through a mix of independent energy counsellors subsidised by the project (like ZEROhome) and the builders trained by GBG (like ESCO-light).

GBG has also organised several energy fairs in participating municipalities, which give the trained builders the opportunity to present examples of their renovations to the public. Keynote speakers make presentations at the fairs on themes ranging from sustainable islands or villages to more technical issues such as solar energy.

Another successful activity organised by GBG has been evening schools on energy renovations that provide participants with tools to identify the potential for energy savings as well as techniques and know-how to renovate their house themselves. These evening schools have attracted citizens who are willing to pay for these classes to learn about home energy renovation in their homes.

GBG was awarded the prize of the best 'private-public partnership' in 2012 by the Danish Fund for Corporate Social Responsibility (CSR). It was also nominated as one of the five finalists in the RegioStars Award of the European Commission in the category of Sustainable Growth in Small and Medium Enterprises (SMEs).

\section{The value of the energy renovation models: Similarities and differences}

The four models presented above represent different ways of motivating private households to conduct energy renovation. All models have met their own targets in the sense that they have resulted in numerous energy renovations in private households. But these models differ in terms of the role of the energy adviser, the financing model, the project evaluation methods, the value of community vs. individual approaches and the strategy adopted to motivate private households. We now turn our attention to these five factors. 


\section{The role of the energy adviser}

Energy advisers play an important role in reducing energy consumption in private households by providing home visits and personal advice about the possibility for energy renovating. Through face-to-face interaction, they relate directly to the people in their private households and thus are able to influence homeowners' choices enormously. They also become an informational instrument for the families because they offer expert knowledge on the subject (Mahapatra et al. 2011a).

As external actors who meet people directly in their homes, the builders' approach to the members of the households depends on qualities such as impartiality, credibility, trust, personality and competence. But what do these factors mean and what are their values?

An energy adviser can be a representative of the municipality, the energy company or an independent builder. Representatives from the municipality or energy company are usually considered impartial, while builders can easily be considered partial, since they have a vested interest in securing a renovation contract. Moreover, potential clients may feel that the builders as energy advisors lack an overview of the different possibilities that exist for house energy renovations. In this light, builders may be expected by potential clients to be more interested in recommending a renovation he can perform rather than a renovation that a builder specialised in another area can perform. People may feel that an impartial energy adviser will give them the neutral overview they need.

Literature on the role of the energy advisers also indicates that impartiality is considered more valuable than working for a profit motive because it gives homeowners a sense of trustworthiness (Rogers 2003; Mahapatra et al. 2011a). Trust in this context is to be understood not just as a state of mind, but as an inter-subjective process with a relational quality (Möllering 2001; Jimenez 2011). Trust is knowledge- and competence-based (Lewicki and Bunker 1996), which means that the energy adviser creates trust through the robust knowledge and expertise that he delivers. However, people will always interpret his knowledge and expertise according to their reality and experiences (Möllering 2001; Jimenez 2011). Conveying the right technical knowledge about the house is therefore not always convincing enough to the families, but requires an understanding of their particular way of living in the house. This aspect of the motivation of the private households is clarified later in this chapter.

Also, the personality of the energy adviser plays an important role. Being an energy adviser is considered a service trade, which means that their behaviour, emotions and attitudes affect service quality (Wilson and Frimpong 2004). The homeowners can be seen as customers who meet the energy adviser with preestablished expectations regarding service quality; if these expectations are not met, homeowners are more likely to feel that the service they received was insufficient (Schneider and White 2004). Besides hiring a builder who exhibits a pleasant demeanour, homeowners tend to want an energy advisor who has both 
good communication and technical skills. These are also the skills that the energy advisers themselves point out as important for fulfilling their role (Mahapatra et al. 2011b).

What is important to note is that although there will always be a suspicion that a builder will be biased when working as an energy adviser, his knowledge, experience and personality can create credibility, and help him convince his potential client that he is interested in investing in certain energy renovations.

Credibility, like impartiality, can generate trust. Many families choose to talk to a builder who has been recommended by neighbours and friends; in these cases, the families are predisposed to trust the builder from the very beginning of their business relationship. Certain builders also manage to create a trustworthy relationship with the homeowners because of their personality traits and convincing nature. This was the case in the ESCO-light project, where one builder performed half of the total energy advice and energy renovation in the project because he was extremely good at promoting himself. One of his strategies was to offer two bottles of wine to any family he visited as an energy adviser. This gesture, along with his personality, helped create a close and trustworthy relationship with the homeowners.

Impartiality and/or credibility are therefore important values in a good energy adviser. Impartiality refers to the energy adviser who is not biased by economic interests, while credibility refers to the energy adviser who, although representing a building company, nevertheless manages through his personality to be convincing. Both impartiality and credibility are based on trust that is achieved by conveying knowledge, information, competence and expertise.

\section{Financing}

Money is a powerful incentive in environmental management (Perman et al. 2003; Millard 2012). In the projects described above, the payback time and the money saved are the most important arguments used by energy advisers and builders to convince people to invest in energy renovation. Converting the number of $\mathrm{kWh}$ a family can save on an energy renovation into a sum of money in order to make the economic benefits as visible as possible makes a renovation project more understandable and attractive to people.

Most energy renovation projects are economically advantageous, but vary in payback time. For example, changing an old electric bulb with a low-energy bulb will usually pay back in one or two years. Most people can afford this purchase on the spot, while investing in a solar panel system may require a loan and take up to ten years to pay back.

However, banks require a guarantee that the money borrowed is invested reasonably and will be repaid in time. The problem is that energy consumption in private households varies a good deal, and energy savings are difficult to use as a loan guarantee. Consequently, until recently, most banks had no specific product to finance private energy renovation. Both ESCO-light and ZEROhome approached local banks to help overcome this problem. Since then, local banks 
have sent some of their employees for training on energy renovation and devised new products specifically adapted to finance energy renovation.

Subsidies can also help trigger new energy renovations. Because local energy companies are required by the state to realise consequent energy savings and are interested in buying the energy savings realised in private households, this constitutes a new type of subsidy that depends on the size of the renovation projects and can amount to between 500 DKK (67 Euros) for medium-sized investments and 5,000 DKK (672 Euros) for the biggest projects. Whilst this subsidy represents only 1 or 2 per cent of the total cost, it nevertheless generates a certain amount of interest among potential renovation clients.

Moreover, with time and increasing pressure on energy companies to save on energy, there is the hope that the price paid for each $\mathrm{kWh}$ saved (between 0.20 and 0.25 DKK, or 0.03 Euro, in 2012) will increase and become a real incentive for renovating. To give an idea of the impact that a higher price may have, ESCO-light decided to buy the first $100,000 \mathrm{kWh}$ saved at a price of 1 DKK ( 0.13 Euro) per $\mathrm{kWh}$ in order to speed up the launching of the project. The first $100,000 \mathrm{kWh}$ were saved within three weeks, even before all neighbourhoods in the municipality had been made aware of this possibility (which created frustration among those who were informed too late). Subsequent $\mathrm{kWh}$ were bought at the price of $0.24 \mathrm{DKK}$ (0.03 Euro), but the pace of energy renovation was then much slower than when the subsidy was four times higher.

Few people know about the possibility of their selling their energy savings to energy companies - even fewer know how to do it. Public-private partnership projects can play an important role in informing citizens about this opportunity, and in bridging the gap between them and energy companies. The ESCO-light model provides the easiest process for people to sell their energy savings - in fact, this process is an important goal of the project. In this model, the builders, after receiving appropriate training, calculate the energy savings and work as administrative mediators between their clients and energy companies. The builders who have been trained in calculating energy savings have an advantage over their competitors who are unable to facilitate the same subsidy to clients.

The ESCO-light model has advantages for all actors. The energy company outsources the administrative cost of calculating energy savings and checking that they have been correctly realised to builders. Builders are able to propose a new subsidy to their client, which can help them gain more contracts. Private individuals can apply the subsidy to their energy renovation costs. And municipalities reduce $\mathrm{CO}_{2}$ emissions and can document that they have created new green jobs.

In ZEROhome, it is the energy advisor (employed by the local energy company) who encourages people to sell their energy savings directly to the energy company and who offers to help with the application. Energy companies are making it increasingly easier for individuals to sell their energy savings, but this possibility is still largely ignored by the general population. This means that builders and energy advisers can still benefit from their position as middlemen as more people become aware of this possibility in the future. 


\section{Project evaluations}

All projects need to be evaluated, but measuring the impact in terms of number of jobs created or tons of $\mathrm{CO}_{2}$ saved is not an easy task (see Strobel et al. in Chapter 2 of this book). When evaluating such projects, 'additionality' is a key concept. What project leaders need to demonstrate in order to justify their budget and actions is not so much how much was achieved during the time frame of the project but, more importantly, how much was achieved that would not have been achieved without the project. In other words, how much did the project 'add' to the process when compared to normal practices? Additionality can best be measured when compared to a base-line measured prior to the renovation project, but this is rather difficult to establish. Instead, these projects often measure their success by recording how many renovation projects have been completed after the visit of one of the project's energy advisers, and how much money was spent and how many jobs have been created by the project.

For example, the ZEROhome project reports that its energy adviser has visited 1,109 families, of whom 61 per cent have made an energy renovation of their house for an average price of 153,000 DKK (20,567 Euros). The total price of energy investments for all these houses is 103 million DKK (13.85 million Euros). The ESCO-light project can document that its builders have realised energy renovations that led to a savings of more than one million $\mathrm{kWh}$ in a year.

However, this method of evaluating projects is problematic. First, it does not take all incentives into account. For example, much of the energy renovation claimed by ZEROhome consists of the installation of solar-panels that were generously subsidised by the state during the project period. These subsidies have been drastically reduced by the state since then, which led to a drop in energy renovation projects as measured by the project.

Second, people requesting a visit by an energy adviser are often people who have already decided to invest in energy renovations and who want advice on the best way to do it. Many of these people would probably renovate their house anyway, with or without the visit of an energy adviser from the project. For example, a telephone survey was conducted by our research team of the people recorded as having received the visit of a builder/energy adviser from ESCO-light and having subsequently conducted an energy renovation. A total of 80 per cent of survey respondents declared that they had not heard about ESCO-Light and would have invested in energy renovations anyway, whilst only 20 per cent declared that they contacted their construction worker specifically in order to benefit from ESCO-Light's conditions.

In May 2013, GBG claimed to have triggered energy renovations in 1,250 houses for a total of 90 million DKK (12.1 million Euros), saving between 1800 and 3600 tons of $\mathrm{CO}_{2}$ and creating an estimated 150 jobs (COWI 2013). Although the method used to evaluate these numbers is not well-documented, GBG also used data provided by Statistics Denmark (the central ministerial authority on Danish statistics), and compared the business levels of the builders trained and involved in GBG with the business levels of other builders working 
in the same municipality. This compilation demonstrated that the business of GBG builders improved by 29 per cent on average between 2010 and 2012, at a time when the building sector was severely hit by the global financial crisis and was stagnating. This difference accounts for the direct creation of 90 new fulltime jobs in that period which, although below the 150 jobs announced in the COWI report, is a significant achievement.

Of course, one can wonder whether the 29 per cent increase in business is a consequence of the builders' participation in GBG, or whether the participation of these builders in GBG was a consequence of their success prior to the GBG project. Certainly builders' business levels are not just linked to energy renovation. But the point we wish to make here is that evaluations require good base-lines.

\section{Individual versus community approaches}

Changes in environmental behaviour can be addressed either individually or collectively, and the approaches taken can lead to very different results (Gausset 2013). A focus on individual choices generally relies on transferring knowledge, raising awareness and using economic (dis)incentives (see e.g. Ajzen 1991; Godin and Kok 1995; Armitage and Conner 2001; Kollmuss and Agyeman 2002; Marteau et al. 2009). This approach is described as the 'ABC model' (Attitude, Behaviour and Choice, see Shove 2009). A focus on collective action, on the other hand, appeals to norms, values, social compliance and collaboration (Schwartz 1977; Dunlap and van Liere 1978; Cialdini et al. 1990; Stern et al. 1995; Hoffmann and High-Pippert 2010). While individual approaches resonate with egoistic motives to improve one's own livelihood and well-being, collective approaches appeal to people's morale and consciences, their will to do good not just for themselves but for others and their will to conform to social expectations.

Both ZEROhome and ESCO-Light addressed energy renovation at the level of households. They relied on relatively classic individual approaches based on increasing knowledge and awareness (through the visit of energy advisers) and economic incentives (in the form of subsidies or future energy savings). There is, however, an increasing recognition of the limits of these individual approaches, and of the need to address behaviour change through groups (Shove 2009; Hoffmann and High-Pippert 2010). Community is slowly emerging as a new trend in promoting energy-friendly behaviour, but very few programmes work with such an approach, as experience is still lacking in the area, and the success of the approach varies from case to case (Walker 2011). MyClimatePlan is a good example of such a collective approach.

By the simple fact that it only helps groups of a minimum of 10 households, MyClimatePlan triggered a social dynamic: neighbours talked to one another. According to our interviews, MyClimatePlan did succeed in reaching some 'environmental sceptics' who were convinced by their neighbours to join the group and invest in energy renovation. People can be drawn into a project not because of a particular interest in the specific project, but because of the influence of a network of friends or acquaintances. Recruitment into community 
energy programmes can be more successful when conducted through a network of personal contacts and neighbourly relations rather than by reading adverts placed in newspapers (Verba et al. 1995; Hoffmann and High-Pippert 2010; Mahapatra et al. 2011a; Tjørring 2013). Instead of being confined within the four walls of the individual household, a collective approach can promote the issue of energy renovation through social networks, where it can reach people who are normally immune to adverts in the traditional media.

It is also easier and less time-consuming to be part of a group, since the bulk of the administration is usually done by a few enthusiasts for the benefit of the group. It is also less risky to conduct energy renovation as a member of a group. Housing renovation often represents heavy investments and long and sometimes disruptive building processes in which many things can (and do) go wrong. Many frightening stories of incompetent builders circulate, e.g. of builders who sometimes go bankrupt in the middle of a project, which can be a major obstacle to energy renovation. Renovating one's house as part of a larger group that is using the same builder gives more power leverage and more security to the individual household. It also has the advantage of speeding up the renovations because it forces people to move at the same pace as others if they want to benefit from group reductions and do not want to be left to deal with their renovation project on their own. On the downside, however, the pressure to use the same builder to renovate 10 houses can generate some frustration when the builder chosen by the group does not enjoy the full confidence of all members of the group.

But community approaches are more complex than individual approaches, and can also fail. For example, the ZEROhome project also experimented with addressing communities. The energy adviser made contact with a village and arranged for several households to receive communal energy advising at only one house. All people met in the selected house and were taught energy renovation, using the host's house as an example. The plan was that the participants could serve afterwards as energy advisers for the rest of the village and would go from door-to-door to convince people to invest in energy renovations.

However, in practice, participants did not feel well-equipped to serve as energy advisers for other families; nor did they feel they had the time to do so. People in the village also felt it was more of a burden than an advantage to take part in the project. Another important aspect is that such projects rely heavily on a few local passionate participants who volunteer time and energy (Verba et al. 1995; Hoffmann and High-Pippert 2010). An important lesson to be learnt in this regard is that community approaches do not automatically equal success they require hard work.

This was also the case in the MyClimatePlan project, where one or two locals ended up doing most of the work of spreading the word and motivating neighbours and friends to join the collective energy renovation project. Whilst community approaches can be an effective tool to reach environmental sceptics or people who are immune to individual approaches, they are also more complex: their success depends on the way they are designed and whether they take the local context into account. 


\section{Motivation of private households - the issue of 'comfort'}

When communicating with the private households, the energy advisers usually stress two main motivational factors: money and comfort. The argument is that people in the long run can save money on an energy renovation and enjoy a more comfortable house. It is well-known that there are good economic incentives to investing in energy renovations, and the energy advisers tend to focus on this aspect when communicating with people. They tend to place all other incentives under the umbrella of 'comfort', including having a warmer house or the healthy effects of a new and more effective ventilation system.

Yet, our qualitative interviews with homeowners indicate that this very broad concept of comfort and people's perceptions of home have a strong influence on their decisions on energy renovations. A house is not just a shell protecting us from the cold outside, but a home in which our lives unfold; it is where we engage in activities and in our relationships (Ingold 2000). When buying a house, we do not just look at the technical quality of the walls, the windows and the kitchen. Rather, we imagine how our life is going to be expressed in the house, what we can do in the different rooms and in what way the house facilitates our social life.

An illustration of this is found in one of our cases, in which a family debated whether they should invest in cavity wall insulation (insulation of the gap inside the outer wall, which is often found in older houses) or a new front door. The energy adviser advised them that the wisest decision economically would be to choose cavity wall insulation because the payback time was very short and they would save a lot of money on their energy bill.

However, the family kept focusing on the need to change the front door because they constantly felt a draught. The family ended up choosing to replace the door instead of insulating the walls, and most energy advisers would tend to label this decision 'for comfort reasons'. However, complex perceptions of life and home are hidden behind this label. It was not just a matter of being affected by the constant draught from the door (in fact, the draught could be considered minimal because the door was in a hallway that people just passed through). It was also about the door being a central entrance point to the house that did not 'look good'. In other words, the door's lack of aesthetics did not match the family's idea of what a nice home should look like and what they felt good about showing the neighbours. This was a matter of constant visibility. When walking in and out of the door, the homeowners were constantly reminded of it: the door was automatically more visible in their minds than cavity wall insulation.

Another important aspect of understanding comfort is that a family is not a homogenous unit: it consists of different family members with different attitudes about their home and different practices within the home. Some rooms are used more than others and, depending on the individual, different values are given to different aspects of the house. For example, family members who spend a lot of time cooking tend to prioritise renovating the kitchen over others, while garden enthusiasts tend to value putting time, money and effort into the land surrounding the house. 
There are interesting differences between how men and women use and prioritise the house. Many popular articles about the matter (such as Bolius 2013, among others) claim that men are more involved in maintenance, repair work and measuring and paying for utilities in the house, while women are more involved in interior design and shopping for the house. This classic division of labour is also reflected in our fieldwork findings: men are associated with the technical aspects of the house, while women are associated with 'creating the sense of home'.

For example, a lot of women resist installing energy-saving light bulbs in the home because they are very concerned about the quality of the light, or resist turning down the underfloor heating in the bathroom because it affects their perception of what a nice bathroom is. In general, energy advising projects tend to focus mainly on the technical aspects of the house. Most energy advisers are men, as are builders or engineers, which are male-dominated professions that focus on technical matters. As a consequence, the language spoken during an energy adviser's visit is directed largely at men and is expected by the families to be directed at men, for which reason the man is usually the person who meets the energy adviser in the home. Insight into the way women think and act in the house is usually lacking.

Comfort and perceptions of home are also closely tied to the different phases of life people go through. People tend to be more prone to investing in energy renovations when they are already planning to do something about the house. Wanting to change the house often happens along with important landmarks in the course of people's lifetimes, including marriage, divorce, moving to another house, having children or when children move away from home. These are significant moments that are often followed by a desire to change one's current or future home. For example, when marrying and moving into a new house, a couple often feels the urge to make the house their home by rebuilding rooms, changing the garden or putting in a new kitchen.

This knowledge about people's lives creates obvious opportunities to promote energy renovations that fit into people's ways of life. None of the energy advisers in any of the projects described above seem to include these considerations about the meaning of comfort and life in their work. However, the aforementioned communication skills that energy advisers wish to develop might refer precisely to this: the need to better understand the way people in private households live their lives and at what times they are particularly apt to make changes and invest in their homes. Such insights make it possible to talk the language of the homeowners and spur more energy renovations.

\section{Conclusion}

In the comparison of the different projects of energy renovation, five aspects appeared as important focal points for discussion, i.e. topics that all the energy renovation projects address in designing their projects. These topics are the role of the energy adviser, financing issues, project evaluation, individual vs. community 
approaches and motivations of the individual households. The projects differed from each other in the way they approached these different topics. There is, of course, no simple answer as to what works best, but it has been shown that impartiality and credibility are important values in an energy adviser, that economic incentives can trigger renovations, that projects need to be evaluated with sound base-lines and that community approaches have the great advantage of reaching sceptics and making energy renovations 'talked about'.

What is not made explicit in any of the energy renovation models, but nevertheless seems to hover beneath the surface, is the value of empathy, which is understood as the capacity to put oneself in another person's place. There seems to be a gap between what the energy advisers think people want and what people really want. Energy advisers tend to approach people's houses as mere technical constructions and focus on the financial benefits of energy renovation instead of focusing on peoples' houses as homes. The commonly used concept of comfort is used to cover this 'soft value'.

However, such labelling reduces more than it enhances the huge potential that lies in unfolding the concept of comfort and focusing on gaining insight into people's lives and perceptions of home. If we place more focus on the energy adviser's capacity for empathy, we place him or her in the midst of the homeowners' lives and not as an external expert on the house who merely views the house as a technical construct. This empathy makes it possible for the energy adviser to talk the language of the homeowners. It is also the strength we find in the community approaches, because neighbours generally have better insights into each other's lives and can talk directly to the needs of a person. Energy renovation projects would gain much by focusing more on the lives lived within the buildings to be renovated, and by talking more about homes rather than about houses.

There are, of course, various actors at play in the challenge of increasing the number of energy renovations in the private housing stock. On the one hand, there are the citizens who own the houses, and on the other hand are the energy companies, builders and political authorities, who have their own particular interest in motivating people to make energy renovations to their private houses. These actors play an important role as facilitators of the process. Citizens influence and are influenced by their surroundings, and the energy companies, builders and political authorities can and do actively engage in promoting energy renovations in private households.

However, the energy companies, builders and political authorities often focus on influencing citizens to make an energy renovation rather than being influenced by citizens and letting that be the starting point for promoting energy renovations. This would require focusing on understanding citizens' daily lives and promoting solutions that are in touch with homeowners' daily practices and their own understanding their home, so that making an energy renovation becomes an easier choice than not making an energy renovation. 


\section{Acknowledgements}

We are grateful to all the employees at ZEROhome, MyClimatePlan, ESCOLight and Green Business Growth for providing us with information about the projects and for facilitating our field work. We would also like to thank all project participants who welcomed us into their homes and shared their insights with us.

\section{References}

Ajzen I (1991) The Theory of Planned Behavior, Organizational Behavior and Human Decision Processes 50 179-211.

Armitage C and Conner M (2001) Efficacy of the Theory of Planned Behaviour: A MetaAnalytic Review, British Journal of Social Psychology 40 471-499.

Bolius (2013) (www.bolius.dk/alt-om/boliglaan-og-oekonomi/artikel/maendenebestemmer-over-boliglaanet/) Accessed 22 May 2013.

Cialdini R, Reno R and Kallgren C (1990) A Focus Theory of Normative Conduct: Recycling the concept of norms to littering in public places, Journal of Personality and Social Psychology 58 749-758.

COWI (2013) Grøn Erhvervsvækst Slutevaluering [Green Business Growth Final Evaluation Report], Project Number A037714-003.

Danish Ministry of Climate, Energy and Building (2011) Energistrategi 2050 - fra kul, olie og gas til grøn energi, Klima-og Energiministeriet, Copenhagen.

Danish Energy Agency (2012) (www.ens.dk/sites/ens.dk/files/info/tal-kort/statistiknoegletal/aarlig-energistatistik/energistatistik2012.pdf) Accessed 19 March 2014.

Dunlap R and Van Liere K (1978) The New Environmental Paradigm: A Proposed Measuring Instrument and Preliminary Results, Journal of Environmental Education 9 $10-19$.

Energispareaftale (2012) (www.danskenergi.dk/Holdning/Energieffektivitet/Aftale.aspx) Accessed 22 January 2015.

Gausset Q (2013) Comparing Different Approaches to Addressing Environmental Behavioural Change: A Review of Ten Case Studies from Denmark, Transdiciplinary Environmental Studies 12 (1) 30-40.

Godin G and Kok G (1995) The Theory of Planned Behavior: A Review of Its Applications to Health-Related Behaviors, American Journal of Health Promotion 11 $87-98$.

Hoff J and Strobel B (2013) A Municipal 'Climate Revolution'? The Shaping of Municipal Climate Change Policies, The Journal of Transdisciplinary Environmental Studies 12(1) 3-14.

Hoffman S M and High-Pippert A (2010) From Private Lives to Collective Action: Recruitment and Participation Incentives for a Community Energy Program, Energy Policy 38 7567-7574.

Ingold T (2000) The Perception of the Environment: Essays in Livelihood, Dwelling and Skill Routledge, London.

Jimenez A C (2011) Trust in Anthropology, Anthropological Theory 11 177-196.

Kollmuss A and Agyeman J (2002) Mind the Gap: Why Do People Act Environmentally and What Are the Barriers to Pro-Environmental Behavior? Environmental Education Research 8(3) 239-260. 


\section{Tjørring and Gausset}

Lewicki R J and Bunker B B (1996) Developing and Maintaining Trust in Work Relationships, in Kramer R M and Tyler T R (eds) Trust in Organizations, Sage, Thousand Oaks, CA, 114-139.

Mahapatra K, Nair G and Gustavsson L (2011a) Energy Advice Service as Perceived by Swedish Homeowners, International Journal of Consumer Studies 35 104-111.

Mahapatra K, Nair G and Gustavsson L (2011b) Swedish Energy Advisers' Perceptions Regarding and Suggestions for Fulfilling Homeowner Expectations, Energy Policy 39 4264-4273.

Marteau T M, Ashcroft R E and Oliver A (2009) Using Financial Incentives to Achieve Healthy Behaviour, BMJ 338 983-985.

Millard M (2012) Environmental Economics, World Technologies, Delhi, India.

Möllering G (2001) The Nature of Trust: From Georg Simmel to a Theory of Expectation, Interpretation and Suspension, Sociology 35(2) 403-420.

Perman R M Y, McGilvray J and Common M (2003) Natural Resources and Environmental Economics, Pearson Education, Edinburgh, UK.

ProjectZero (2013) (www.projectzero.dk/da-DK/Artikler/2013/Marts/Regeringens-kliman\%C3\%B81-koster-arbejdspladser.aspx) Accessed 5 January 2015.

Rogers E M (2003) Diffusion of Innovations, The Free Press, New York.

Schneider B and White S (2004) Service Quality: Research Perspectives, Sage, Thousand Oaks, CA.

Schwartz S (1977) Normative Influences on Altruism, Advances in Experimental Social Psychology $10222-279$.

Shove E (2009) Beyond the ABC: Climate Change Policy and Theories of Social Change, Environment and Planning 42 1273-1285.

Stern P, Dietz T and Guagnano G (1995) The New Ecological Paradigm in SocialPsychological Context, Environment and Behavior 27(5) 723-743.

Tjørring L (2013) The Power of Practice and Community: A Case Study of Environmental Living in El Bolson, Argentina, Transdiciplinary Environmental Studies 12(1) 41-52.

Verba S, Schlozman K L and Brady H E (1995) Voice and Equality: Civic Voluntarism in American Politics, Harvard University Press, Cambridge MA.

Walker G (2011) The Role for Community in Carbon Governance, Wiley Interdisciplinary Reviews Climate Change 2(5) 777-782.

Wilson A and Frimpong J (2004) A Reconceptualisation of the Satisfaction-Service Performance Thesis, Journal of Social Marketing 18 471-481. 